\title{
VOLATILE SHELL-INVESTIGATION CUES OF LAND HERMIT CRABS: Effect of Shell Fit, Detection of Cues from Other Hermit Crab Species, and Cue Isolation
}

\section{ROBERT W. THACKER}

\author{
Department of Biology \\ University of Michigan \\ Ann Arbor, Michigan 48109-1048
}

(Received November 2, 1993; accepted January 21, 1994)

\begin{abstract}
Land hermit crab responses to volatile shell-investigation cues from land hermit crabs and from marine hermit crabs are analogous to the responses of marine hermit crabs to shell-investigation cues from marine crabs and from snails. Land hermit crabs attracted to shell cues are in worse-fitting shells and are more likely to investigate conspecifics' shells than are crabs attracted to feeding cues. Moving land hermit crabs from worse shells to better shells decreases the number of crabs investigating shells, while moving crabs from better shells to worse shells increases the number of crabs investigating shells. Gravid females have better-fitting shells than nongravid females or males. Crabs from two different populations in Panama have different shell fits and show different levels of responses to shell-investigation cues. Land hermit crabs respond to volatile shell-investigation cues from both land and marine hermit crabs, but marine hermit crabs do not respond to cues from land hermit crabs. A cue detection system for volatile cues most likely evolved in land hermit crabs during their transition from a marine to a terrestrial existence. Thus, the cues found in land hermit crabs and marine hermit crabs may be chemically similar. Volatile compounds collected from hermit crabs onto Tenax columns can be eluted with ethanol and act as shell-investigation cues in field assays.
\end{abstract}

Key Words-Land hermit crabs, Coenobita, Calcinus, Clibanarius, Crustacea, chemical cues, shell fit, shell acquisition, behavior.

\section{INTRODUCTION}

A critical activity for hermit crabs is locating gastropod shells. Hermit crabs use shells to obtain protection from predators and desiccation (Hazlett, 1981). Shell 
type and quality can influence a hermit crab's reproductive success (Bertness, 1981; Hazlett, 1989; Hazlett and Baron, 1989). The supply of shells can limit the size of hermit crab populations (Provenzano, 1960; Childress, 1972; Vance, 1972; Bach et al., 1976; Kellogg, 1976; Spight, 1977).

Marine hermit crabs can locate shells by detecting two types of chemical cues. Gastropod predation sites provide an intact gastropod shell whose occupant has been digested by a predatory gastropod (McLean, 1974; Rittschof, 1980a). Marine hermit crabs are attracted to these sites by peptides released during the digestion process (Rittschof, 1980b; Rittschof et al., 1990; Kratt and Rittschof, 1991). Marine hermit crabs are also attracted to cues released from the hemolymph of damaged, dead, or dying conspecifics (Rittschof et al., 1992). Marine hermit crabs attracted to either gastropod cues or marine hermit crab cues actively search for shells at cue sources and vigorously investigate the shells of other hermit crabs that are attracted to cue sources (McLean, 1974; Rittschof, 1980a; Rittschof et al., 1992).

Land hermit crabs, Coenobita spp., are attracted to volatile chemical cues released from dead conspecifics and actively investigate shells at cue sources by touching the shells with their chelipeds and walking legs (Small and Thacker, 1994). Unlike marine hermit crabs, land hermit crabs do not respond to dead gastropod odors with shell-investigation behaviors, but rather with feeding behaviors (Rittschof and Sutherland, 1986).

In this paper, I describe experiments that characterize the nature of land hermit crab shell-investigation behavior and the cues that stimulate this behavior. I differentiate between the effects of visual and olfactory stimuli and suggest that some land hermit crabs are more attracted to olfactory feeding cues, while others are more attracted to olfactory shell cues. A physical factor that could influence shell-investigation behavior in land hermit crabs is shell fit. I report that land hermit crab attraction to shell cues and execution of shell-investigation behaviors are correlated with poor shell fits. I show that shell fit varies between sexes and that differences between populations in shell fit are correlated with differences between populations in shell-investigation behavior.

As land hermit crabs have colonized the terrestrial environment, they have retained the ability to locate shells by detecting cues from dead conspecifics. The transition from a marine existence to a terrestrial existence has required a change in this signaling system from a nonvolatile peptide cue to a volatile cue. The pattern of this change was examined by determining if two species of land hermit crabs respond to shell cues from each other or from marine hermit crabs. I also determine if marine hermit crabs respond to shell cues released from land hermit crabs. A procedure was devised for isolating land hermit crab shellinvestigation cues to chemically compare them to marine hermit crab cues. 


\section{METHODS AND MATERIALS}

\section{Study Sites and Organisms}

Coenobita compressus H. Milne Edwards, a land hermit crab found on the Pacific coast of the Americas, was studied at two locations. The work was conducted at the Achotines Laboratory of the Inter-American Tropical Tuna Commission (Los Santos Province, Republic of Panama) between January and April, the dry season, of 1992 and 1993. Achotines Bay is bordered by a sandy and rocky beach that is shaded by a tropical dry forest until midday. C. compressus are found on the beach and in the forest and are extremely abundant. These crabs are active in the morning until the beach is no longer shaded and at night, with maximum activity during falling tides at disk and dawn. The experiments were performed between 0600 and $1030 \mathrm{hr}$ and between 1730 and $1930 \mathrm{hr}$.

C. compressus was also studied at the Naos Laboratory of the Smithsonian Tropical Research Institute (STRI), near Panama City, Republic of Panama, from March to May 1993. The site was Culebra Beach, a stretch of sandy beach between two rocky outcrops. $C$. compressus were less abundant at this location than at Achotines and were most active at night, as there was no daytime shading of the beach. Maximum activity occurred on falling tides near dusk. Experiments were conducted between 1800 and $2100 \mathrm{hr}$. Calcinus obscurus (Stimpson), a Pacific marine hermit crab that lives in rocky tidepools, is found at both Achotines and Naos and was studied at each location between $2 \mathrm{hr}$ before and $2 \mathrm{hr}$ after daytime low tides.

Bombacopsis sessilis (Bentham, spiny cedar) flowers are a common food item for $C$. compressus at Achotines. These flowers fall onto the beach in the mornings during the dry season and attract large numbers of feeding crabs. A brachyuran ghost crab, Ocypode gaudichaudii Milne Edwards and Lucas, is also found at Achotines and Naos and was used as an odor source at each location. The shells of Nerita scabricosta Lamarck, an abundant gastropod on rocky substrates at each site, were the most common shells used by $C$. compressus and were also used by $C$. obscurus. N. scabricosta was used as an odor source at each location.

In April 1993, I studied Coenobita clypeatus (Herbst), a Caribbean land hermit crab, and Clibanarius antillensis Stimpson, a Caribbean marine hermit crab, at STRI's Galeta Marine Laboratory, near Colon, Republic of Panama. C. clypeatus was active during the day and night at low abundance on a sand and coral rubble beach. $C$. antillensis occurred in large numbers on a reef flat, intermixed with a large snail population. Both hermit crabs inhabited the shells of Nerita fulgurans Gmelin, a common gastropod in this area, as well as several 
other species of snails. Experiments on both species were conducted between 0700 and $1700 \mathrm{hr}$.

Hemolymph from $O$. gaudichaudii, $C$. clypeatus, and $C$. compressus was obtained by inserting a 22 -gauge needle on a 1 -ml tuberculin syringe into the sinus located on the major chelae of the crab. Over $1 \mathrm{ml}$ of hemolymph could be drawn from large individuals. Tissue extracts were made from $O$. gaudichaudii, $C$. obscurus, $C$. antillensis, $C$. compressus, and $C$. clypeatus with a ratio of $1 \mathrm{~g}$ tissue to $3 \mathrm{ml}$ seawater, and from $N$. scabricosta and $N$. fulgurans with a ratio of $1 \mathrm{~g}$ tissue to $1 \mathrm{ml}$ seawater. After weighing tissue into a 30-ml vial, an appropriate amount of seawater was added and the tissue was homogenized. The mixture remained at ambient temperature for $1 \mathrm{hr}$ before storing it in a refrigerator at $10^{\circ} \mathrm{C}$.

\section{Attraction to Feeding Cues and Shell Cues}

Land hermit crabs could be stimulated to investigate shells by visual cues after arriving at an odor source and finding an empty shell or conspecifics, or they could be stimulated to investigate shells by olfactory cues before arriving at an odor source. To differentiate between visual and olfactory shell cues at odor sources, odor sources were placed in shallow pits to prevent visual cues from affecting crabs as they approached an odor source and to prevent social facilitation by visual cues (Kurta, 1982). The presence or absence of an empty shell at the odor sources controlled for the visual stimulation of an empty shell.

At Achotines, a 30-cm-diameter, 5-cm-deep pit was made in the sand on the beach, and all land hermit crabs within $1 \mathrm{~m}$ were removed. An odor stimulus was then placed in the center of the pit, with or without a clean, empty $N$. scabricosta shell. The test stimuli were a blank control, $B$. sessilis flower, $O$. gaudichaudii, $N$. scabricosta, $C$. obscurus, and $C$. compressus, which were crushed with a rock to facilitate the release of odors. For 4 min after the first crab arrived in a pit, the number of crabs arriving, the number of feeding, and the number investigating the shells of conspecifics that had come to the pit were recorded. An observation period of $4 \mathrm{~min}$ was used because, after than time, such a large number of crabs was present at the pit that individual investigation events could not be recorded accurately. If an empty shell was present, the number of crabs investigating the empty shell and the number of shell exchanges were also recorded. No shell exchanges occurred without an empty shell present. Eight trials with each stimulus were performed in a random order and consecutive trials were conducted in pits at least $10 \mathrm{~m}$ apart. The percent of crabs feeding, percent investigating conspecifics, percent investigating the empty shell, and percent exchanging shells were calculated and analyzed by analysis of variance (ANOVA), transforming percent investigating conspecifics, percent investigating the empty shell, and percent exchanging shells with an arcsine 
transformation to meet the assumptions of normality and homogeneity of variances (Neter et al., 1990). Pairwise comparisons were made of significant effects using the Scheffé method of multiple comparisons (Neter et al., 1990).

\section{Behavior of Crabs Attracted to Different Stimuli}

The previous experiment suggested that $C$. compressus attracted to feeding cues behave differently than crabs attracted to shell-investigation cues. To test this suggestion and to determine if shell fit was correlated with shell-investigation behavior, the behavior of crabs attracted to different odor sources, using a method similar to that of Small and Thacker (1994) was assayed. At Achotines, land hermit crabs in $N$. scabricosta shells that were attracted to a crushed conspecific ( $C$. compressus) or a $B$. sessilis flower were collected. Crabs were also collected haphazardly on the beach and under driftwood. For each of these three groups, 10 crabs were individually marked on their shells with paper correction fluid and placed in a 30-cm-diameter plastic bucket. After $3 \mathrm{~min}$, a crushed $C$. compressus was added, and 3 min later an empty $N$. scabricosta shell large enough for the largest crab in the bucket to use. The crabs were then observed for an additional $10 \mathrm{~min}$ (Small and Thacker, 1994). During each time period, the identity of crabs that investigated conspecifics or exchanged shells were recorded. Before starting and after completing this experiment, the shell fit was measured of each crab using Abrams' (1978) extension-withdrawal categories. This method ranks shell fit into 12 categories, one being a crab most withdrawn into its shell and 12 being a crab most extended from its shell; thus, a larger number indicates a worse shell fit. This experiment was repeated five times for each of the three groups of crabs. The number of crabs investigating conspecifics and exchanging shells in each group was compared using $G$ tests. I compared the shell fits of different crab groups, of investigators and noninvestigators, and of exchangers and nonexchangers using Kilmogorov-Smimov (KS) test (Conover, 1980). Also compared were the proportion of crabs investigating conspecifics in each shell fit category using a $G$ test, pooling every two categories to obtain larger cell values (Sokal and Rohlf, 1981).

\section{Effect of Shell Fit on Shell-Investigation Behavior}

After finding a correlation between shell fit and attraction to feeding cues or shell cues, the probability of an individual's shell fit influencing the probability of that individual engaging in shell-investigation behaviors was determined. At Achotines, crabs in N. scabricosta shells were collected that had good (extension-withdrawal category $<6$ ) or bad (extension-withdrawal category $>7$ ) shell fits and, to control for possible effects of manipulation, each crab was removed from its shell and then allowed to return to its shell. The previously described procedure (see above) was then performed with 10 crabs 
with good shell fits or 10 crabs with bad shell fits. Upon completion of the procedure, each crab was removed from its shell and given access to a shell that worsened (good to bad) or improved (bad to good) its shell fit. The new shell fit was measured and the procedure repeated. Knowing the identity of each individual in the two trials, the number of crabs investigating conspecifics and exchanging shells were analyzed using the McNemar test for significance of changes (Sokal and Rohlf, 1981).

\section{Comparison of Shell Fits between Sites and Sexes}

To test Abrams' (1978) report of shell fit varying between land hermit crab populations and to determine if shell fit varies between sexes, land hermit crabs in $N$. scabricosta shells were collected at Achotines and at Naos, the carapace length and shell length of each crab were measured and its sex determined. For each crab, a shell fit ratio was calculated, defined as carapace length divided by shell length (Rittschof, 1980a). Analysis of covariance (ANCOVA) (Neter et al., 1990) was performed on the shell fit ratios, using carapace length as a covariate and sex and site as grouping variables. Juveniles were analyzed separately from adults, using the smallest-sized gravid female as a size cutoff for the adult category. Juvenile sex categories were male and female, while adult sex categories were male, female, and gravid female. Pairwise comparisons were made of significant effects using the Scheffé method of multiple comparisons (Neter et al., 1990).

\section{Response Time to Shell-Investigation Cues at Different Sites}

Populations in better-fitting shells might be expected to respond less to shell-investigation cues than populations in worse-fitting shells. To test this hypothesis, I determined if differences in shell fit between populations at different sites were correlated with differences in response times to shell-investigation cues. The number of crabs attracted per minute to a 1.85 -ml vial containing $250 \mu \mathrm{l}$ of $C$. compressus hemolymph placed in the center of a $30-\mathrm{cm}$-diameter shallow pit at Achotines and Naos was calculated and data were compared using a two-tailed $t$ test (Sokal and Rohlf, 1981).

\section{Distribution of Shell-Investigation Cues}

Shell-investigation cues released from marine hermit crabs are present in their hemolymph (Rittschof et al., 1992). The following bioassay was performed to determine if land hermit crab shell-investigation cues are present in C. compressus hemolymph and to determine if shell cues could be extracted from $C$. obscurus. At Achotines, $250 \mu \mathrm{l}$ of stimulus fluid was placed in a $1.85-\mathrm{ml}$ vial in the center of a 30 -cm-diameter shallow pit with the lip of the vial $0.5 \mathrm{~cm}$ 
above the sand, and placed an empty $N$. scabricosta shell $2 \mathrm{~cm}$ away from the vial. The stimuli tested were: seawater, a null activity control; $O$. gaudichaudii hemolymph; $N$. scabricosta extract; $C$. obscurus extract; $C$. compressus hemolymph; and $C$. compressus crushed inside a vial, a positive activity control (Table 1). The number of crabs arriving in the first 4 min after the first arrival and the number of crabs investigating conspecifics' shells were recorded. Five replicates of this procedure were performed and the data pooled before analyzing the proportion of crabs investigating conspecifics' shells using a $G$ test for independence (Sokal and Rohlf, 1981). The stimuli were then separated into one group homogenous with the null activity control and one group homogeneous with the positive activity control, using a simultaneous test procedure for unplanned comparisons (Sokal and Rohlf, 1981).

\section{Detection of Shell-Investigation Cues of and by Other Species}

The shell-investigation stimuli of different species were compared by determining if cues from land and marine hermit crabs from both the Pacific and Caribbean coasts of Panama stimulated shell-investigation behaviors in land and marine hermit crabs. Additional bioassays were performed with $C$. compressus to determine if this species responds to shell-investigation cues from $N$. fulgurans, $C$. antillensis, and $C$. clypeatus (Table 1). Bioassays on $C$. obscurus, $C$. antillensis, and $C$. clypeatus were also performed to determine if they respond

Table 1. Stimuli Tested in Shell-Investigation Assays with Four Species of HERMIT CRABS ${ }^{a}$

\begin{tabular}{|c|c|c|c|c|c|c|}
\hline \multirow[b]{2}{*}{ Stimulus } & \multicolumn{6}{|c|}{ Assay $^{b}$} \\
\hline & COM-A & $\mathrm{COM}-\mathrm{N}$ & OBS-A & OBS-N & CLY & ANT \\
\hline Seawater & + & + & + & + & + & + \\
\hline O. gaudichaudii hemolymph & + & & + & & & \\
\hline N. scabricosta extract & + & & + & & + & + \\
\hline N. fulgurans extract & & + & & + & + & + \\
\hline C. obscurus extract & + & & + & + & + & + \\
\hline C. antillensis extract & & + & & + & + & + \\
\hline C. compressus hemolymph & + & + & + & & + & + \\
\hline C. compressus crushed & + & & & & & \\
\hline C. clypeatus hemolymph & & + & & + & + & + \\
\hline
\end{tabular}

${ }^{\text {" }} \mathrm{A}+$ indicates that a given stimulus was used in assays with the respective hermit crab species.

${ }^{b} \mathrm{COM}-\mathrm{A}=C$. compressus cue distribution assay, Achotines; $\mathrm{COM}-\mathrm{N}=C$. compressus filledshell assay, Naos; OBS-A $=C$. obscurus assay, Achotines; OBS-N $=C$. obscurus assay, Naos; $\mathrm{CLY}=C$. clypeatus assay; $\mathrm{ANT}=C$. antillensis assay. 
to shell-investigation cues from each other, $N$. scabricosta, $N$. fulgurans, and C. compressus (Table 1).

C. compressus Filled-Shell Bioassay. At Naos, land hermit crab densities were considerably lower than at Achotines, and crabs were also less active during daylight hours. Crabs responding to a stimulus often did so in the absence of any other crabs, making the observation of investigating conspecifics less frequent. To compensate for these conditions, a different bioassay was used for $C$. compressus at Naos to test responses to seawater, $N$. fulgurans extract, $C$. antillensis extract, $C$. compressus hemolymph, and $C$. clypeatus hemolymph (Table 1). Three $30-\mathrm{cm}$-diameter shallow pits were made $1 \mathrm{~m}$ apart on Culebra Beach and a $1.85-\mathrm{ml}$ vial containing $250 \mu \mathrm{l}$ of stimulus was placed in the center of each pit; $2 \mathrm{~cm}$ away from the vial was placed a $N$. scabricosta shell filled with concrete to mimic a land hermit crab withdrawn into its shell. For a 20min interval, the number of crabs arriving and the number investigating the filled shell at each vial were counted. This longer time interval was used to obtain a greater number of observations of individual crabs. The stimuli were then changed and observations repeated for $20 \mathrm{~min}$, using seawater as a control in each observation period. This procedure was performed on three different nights and the data pooled before analysis using $G$ tests (Sokal and Rohlf, 1981).

C. obscurus and $\mathrm{C}$. antillensis Bioassay. To examine the shell-investigation behavior of marine hermit crabs, the bioassay described by Rittschof et al. (1992) was used: 10 crabs were placed in 3 liters of seawater in a 30-cm-diameter bucket. The crabs were separated manually and mixed with seawater; after 15 $\mathrm{sec}$ the crabs were observed for $1 \mathrm{~min}$, and the number of hermit crabs that investigated another hermit crab's shell was counted. I repeated this procedure, adding $100 \mu \mathrm{l}$ of seawater before mixing the seawater, and then performed a third trial, adding $100 \mu \mathrm{l}$ of stimulus before mixing the seawater. At Achotines, test stimuli for $C$. obscurus were $O$. gaudichaudii hemolymph, $N$. scabricosta extract, $C$. obscurus extract, and $C$. compressus hemolymph (Table 1). At Naos, test stimuli for $C$. obscurus were $N$. fulgurans extract, $C$. obscurus extract, $C$. antillensis extract, and $C$. clypeatus hemolymph (Table 1). At Galeta, test stimuli for $C$. antillensis were $N$. scabricosta extract, $N$. fulgurans extract, $C$. obscurus extract, $C$. antillensis extract, $C$. compressus hemolymph, and $C$. clypeatus hemolymph (Table 1). Five replicates of each stimulus were performed at Achotines and four replicates of each stimulus at Naos and at Galeta, using fresh crabs for each replicate at all locations. The replicates were pooled and the data analyzed by comparing the proportion of crabs responding before addition to the proportion of crabs responding after addition of seawater, and the proportion of crabs responding after addition of seawater to the proportion of crabs responding after addition of test stimulus using $G$ tests, with the proportion responding before addition as an expected value for the proportion responding after addition (Sokal and Rohlf, 1981). 
C. clypeatus Bioassay. Since land hermits at Galeta (C. clypeatus) occurred at a lower density than $C$. compressus at Achotines and Naos, I used a bioassay based on the previously described bucket assay to examine shell-investigation behavior. Ten individuals were placed in a $30-\mathrm{cm}$-diameter bucket and allowed $10 \mathrm{~min}$ to acclimate to the bucket. Next, a plastic bottle cap (15 mm diameter) was placed in the center of the bucket. After $1 \mathrm{~min}$, the crabs were observed for $1 \mathrm{~min}$ and the number of individuals that investigated another crab's shell recorded, scoring each individual only once. I then placed $250 \mu \mathrm{l}$ of extract $(N$. scabricosta, $N$. fulgurans, $C$. obscurus, $C$. antillensis) or hemolymph (C. compressus, $C$. clypeatus) in the bottle cap and again observed investigation behavior for $1 \mathrm{~min}$ (Table 1). Each stimulus was tested with each group of 10 crabs, removing the crabs, and rinsing the buckets three times between trials. Four replicates of this experiment were performed, the stimuli presented in a different order in each replicate, and the replicates pooled for analysis by $G$ test, with the control population fondling used as an expected value for the experimental proportion fondling for each stimulus (Sokal and Rohlf, 1981).

\section{Volatile Cue Isolation and Bioassay}

Volatile shell-investigation cues were isolated by collecting them on TenaxTA (20/35 mesh size), using a method similar to that of Ciccioli et al. (1976) and Patt et al. (1988). Tenax-TA is a porous polyester based on 2,6-diphenyl$p$-phenylene oxide and can be used as an adsorbent to collect organic volatile compounds or as a gas chromatography stationary phase to separate these compounds. A battery-powered pump pushed air through a sealed cup containing an odor source, then through a sampling column, which consisted of a glass pipet tube filled with $300 \mathrm{mg}$ of Tenax, held in place with plugs of steel wool at either end of the tube. Before use, the columns were conditioned by rinsing them with $10 \mathrm{ml}$ (approximately 10 column volumes) of $95 \%$ ethanol and heating them to $200^{\circ} \mathrm{C}$ overnight.

Volatile compounds were collected at $0^{\circ} \mathrm{C}$ by suspending the column in an ice bath. To collect volatiles at $40^{\circ} \mathrm{C}$ and higher, the column was suspended by copper tubing in a drying oven that could be heated to temperatures ranging from ambient to over $200^{\circ} \mathrm{C}$. For any given temperature reported, the oven temperature was within $5^{\circ} \mathrm{C}$ of that temperature. To sample volatile compounds, I first heated or cooled the column to a target temperature and then started airflow through the sealed cup and the column at $20 \mathrm{ml} / \mathrm{min}$ for $15 \mathrm{~min}$. The odor source was then added to the cup and airflow resumed for $30 \mathrm{~min}$. After $30 \mathrm{~min}$, the oven was turned off, the column allowed to cool to ambient temperature and then eluted with $10 \mathrm{ml}$ of $95 \%$ ethanol.

Eluents of $C$. compressus odor made at different temperatures were compared to C. compressus hemolymph (positive control) and ethanol (negative 
control) to determine if they contained molecules that stimulated shell-investigation behavior of $C$. compressus at Naos. Three $30-\mathrm{cm}$-diameter shallow pits were made $1 \mathrm{~m}$ apart, a $1.85-\mathrm{ml}$ vial containing $250 \mu \mathrm{l}$ of stimulus placed in the center of each pit, and a filled shell placed $2 \mathrm{~cm}$ from the vial. For a 20min interval, the number of crabs arriving and the number investigating the filled shell were counted. The positions of the vials were then changed, observations repeated for $20 \mathrm{~min}$, the vials' positions changed a third time, and observations repeated for an additional $20 \mathrm{~min}$. Data were pooled from the three 20-min observation periods and the proportion of crabs investigating the filled shell at the test eluent compared to the proportion at $C$. compressus hemolymph and to the proportion at ethanol using $G$ tests (Sokal and Rohlf, 1981).

To determine if eluents made from the collection of odors from an empty cup, $O$. gaudichaudii, $C$. compressus, $C$. clypeatus, $C$. obscurus, and $C$. antillensis at $130^{\circ} \mathrm{C}$ and $150^{\circ} \mathrm{C}$ stimulated shell investigation, the previous assay was modified. Four 30-cm-diameter shallow pits and three 20 -min observation periods were used to test 12 different fractions each night, repeating the procedure on six different nights, changing the positions and observation periods of the 12 stimuli each night. The data from each night were pooled and the proportion of crabs investigating filled shells compared using a $G$ test (Sokal and Rohlf, 1981).

The previously described C. obscurus assay was repeated using the $130^{\circ} \mathrm{C}$ C. obscurus eluent as a stimulus and seawater and ethanol as controls to determine if the molecules that were shell-investigation cues for $C$. compressus were also cues for $C$. obscurus.

\section{RESULTS}

\section{Attraction to Feeding Cues and Shell Cues}

Since no feeding was possible at empty pits, the control treatment was not included in the analysis of the percent of crabs feeding. Percent feeding varied significantly between different stimulus odors $\left(F_{4.69}=11.00, P<0.001\right.$, Figure 1), while the presence of an empty shell had no effect on feeding $\left(F_{1.69}=\right.$ $0.25, P=0.621$, Figure 1). Pairwise comparisons of stimulus effects showed that significantly less feeding occurred at $C$. compressus odors (all other odor stimuli different from $C$. compressus, $P<0.02$; not different from each other, $P>0.33$ ). The percent of crabs investigating conspecifics varied significantly between different stimuli $\left(F_{5.81}=19.33, P<0.001\right.$, Figure 2$)$ and significantly more investigation of conspecifics occurred in the presence of an empty shell $\left(F_{1,81}=13.88, P<0.001\right.$, Figure 2$)$. Pairwise comparisons of stimulus effects showed that $C$. compressus odors stimulated significantly more investigation activity than the other odors and that $C$. obscurus odors also stimulated a high 


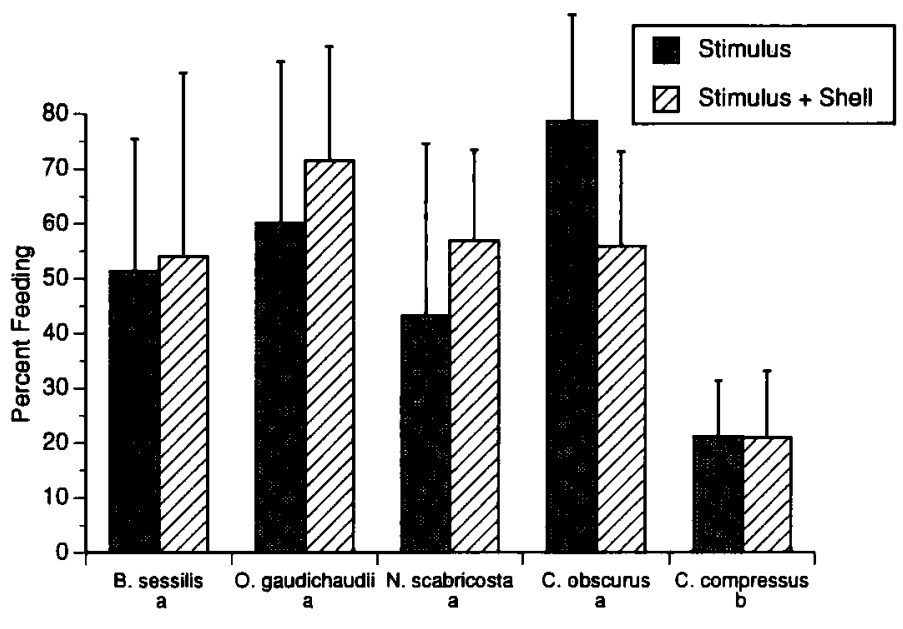

Stimulus

FIG. 1. The percent of $C$. compressus arriving at pits that fed on different odor stimuli. Shaded bars indicate odor stimuli alone, striped bars indicate odor stimuli combined with an empty shell. Identical letters under stimulus names indicate pairs of stimuli that are not significantly different $(P>0.05)$ by Scheffé's multiple comparison test of the effect of stimuli.

amount of investigation activity in the presence of an empty shell, while little investigation occurred at $\boldsymbol{B}$. sessilis sites (Figure 2). The percent of crabs investigating an empty shell did not differ significantly between stimuli $\left(F_{5,41}=\right.$ $1.89, P=0.117$, Figure 3 ). The percent of crabs exchanging shells also did not significantly vary between stimuli $\left(F_{5,41}=1.98, P=0.102\right.$, Figure 4).

\section{Behavior of Crabs Attracted to Different Stimuli}

When the shell-investigation behavior of different groups of crabs attracted to different odors was examined, the number of crabs investigating conspecifics' shells varied significantly between crab groups $(G=10.74>9.21,2 d f, P<$ 0.01 , Figure 5 ), with more investigation shown by crabs that had been attracted to a dead conspecific than to haphazardly collected crabs or crabs that had been attracted to a flower. The number of crabs exchanging shells also differed significantly ( $G=6.23>5.99,2 d f, P<0.05$, Figure 5) with the same pattern between groups. The distribution of crabs in shell-fit categories varied significantly between crab groups, with the group attracted to dead conspecifics having significantly worse shell fits than the group attracted to flowers (conspecificflower: maximum difference $=0.380, P=0.001$; flower-random and conspe- 


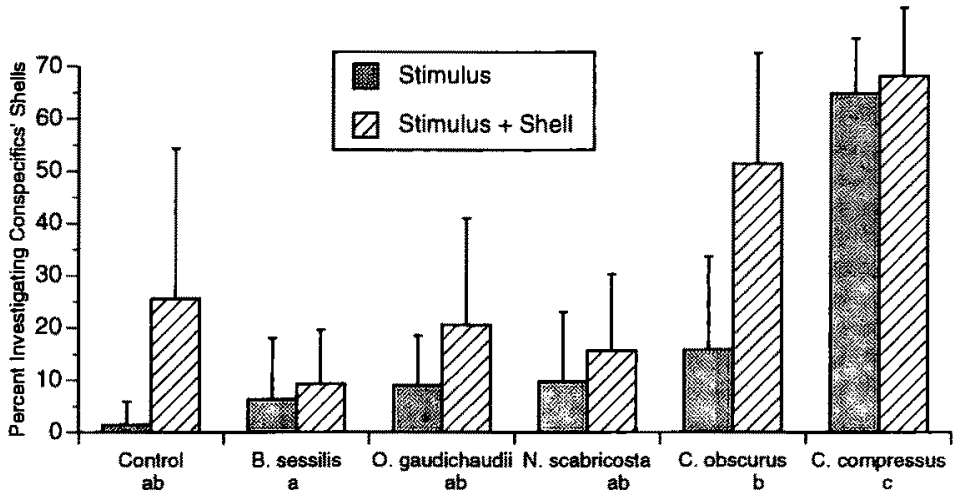

Stimulus

FIG. 2. The percent of $C$. compressus arriving at pits that investigated conspecifics' shells at different odor stimuli. Shaded bars indicate odor stimuli alone, striped bars indicate odor stimuli combined with an empty shell. Identical letters under stimulus names indicate pairs of stimuli that are not significantly different $(P>0.05)$ by Scheffe's multiple comparison test of the effect of stimuli.

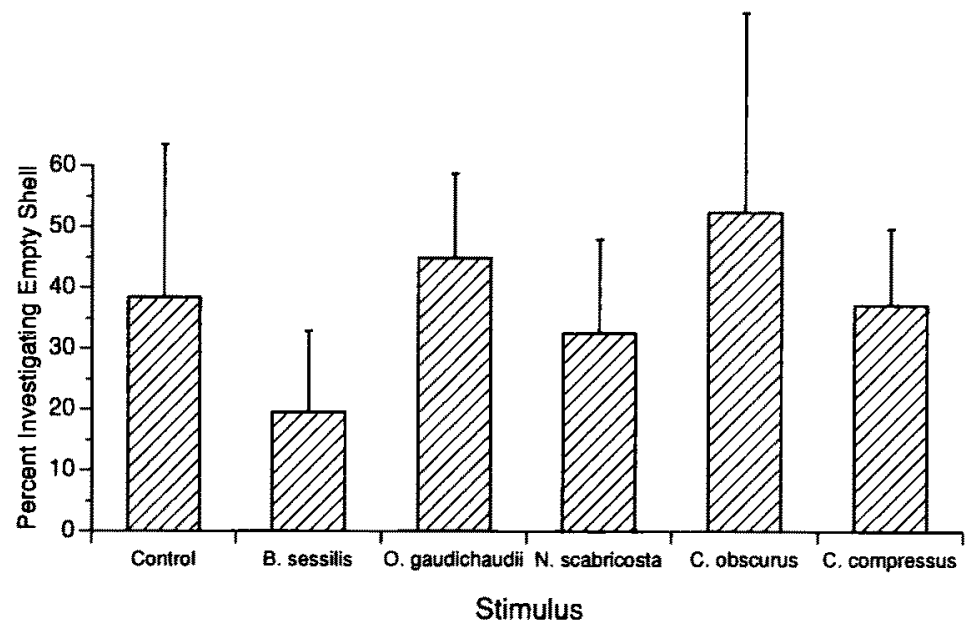

FiG. 3. The percent of $C$. compressus arriving at pits that investigated the empty shell placed at each odor stimulus. 


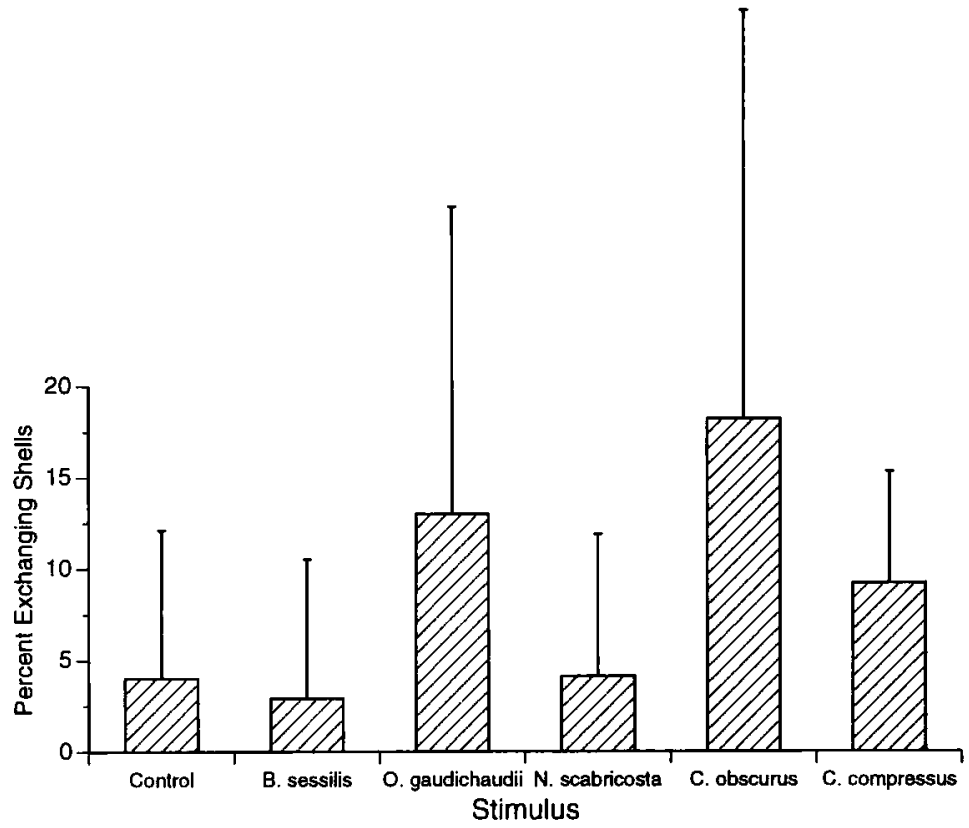

Fig. 4. The percent of $C$. compressus arriving at pits that exchanged shells at each odor stimulus provided with an empty shell.

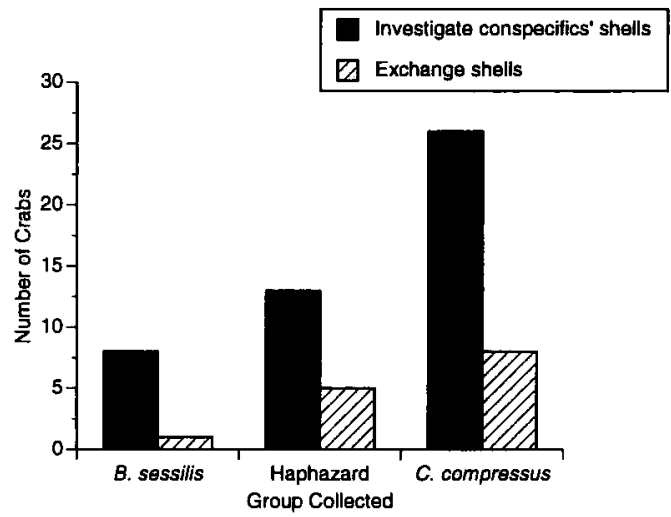

FIG. 5. The number of $C$. compressus investigating conspecifics' shells (shaded bars) and the number exchanging shells (striped bars) in groups of crabs attracted to a dead conspecific ( $C$. compressus), a $B$. sessilis flower, or collected haphazardly. 
cific-random: maximum difference $=0.140, P=0.660$, Figure 6 ). The distribution of shell fits also differed significantly between crabs that investigated conspecifics and crabs that did not, with the investigating crabs having significantly worse shell fits (maximum difference $=0.281, P=0.013$, Figure 7). The same pattern was found in crabs that exchanged shells and crabs that did not, with exchanging crabs having significantly worse shell fits (maximum difference $=0.509, P=0.002$, Figure 8 ). The proportion of crabs investigating conspecifics' shells increased as the shell-fit category increased $(G=18.01>$ $13.28,4 d f, P<0.01$, Figure 9); thus, crabs in poorly fitting shells were more likely to investigate conspecifics' shells than were crabs in better-fitting shells.

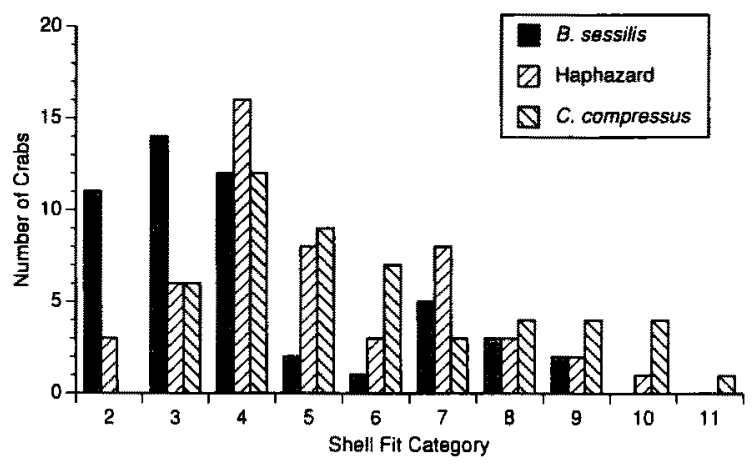

Fig. 6. The number of $C$. compressus in each shell-fit category for groups of crabs attracted to a dead conspecific (C. compressus), a B. sessilis flower, or collected haphazardly.

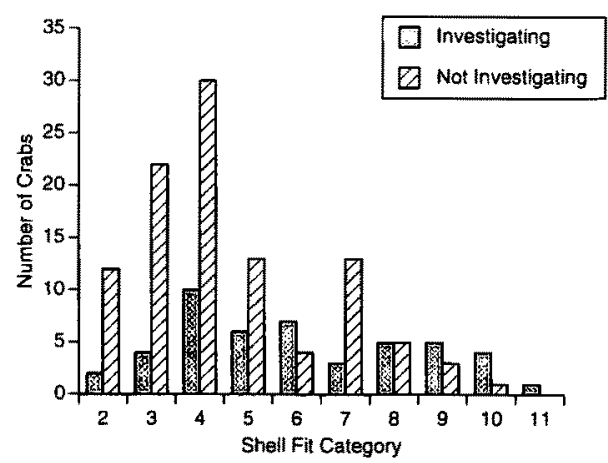

FIG. 7. The number of $C$. compressus in each shell-fit category investigating conspecifics' shells or not. 


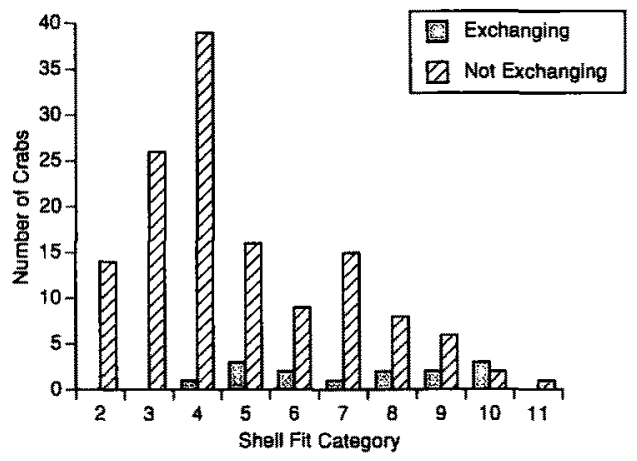

FIG. 8. The number of $C$. compressus in each shell-fit category exchanging shells or not.

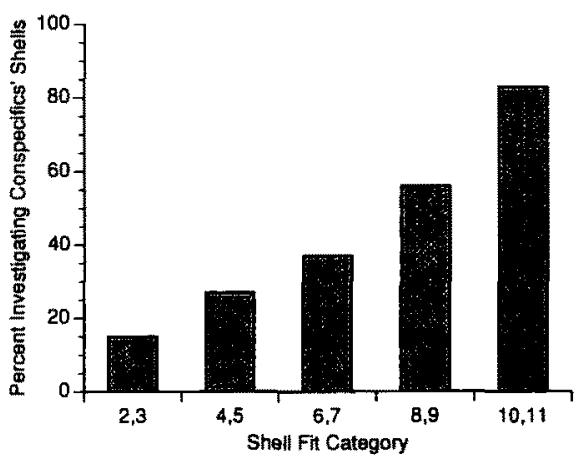

FiG. 9. The percent of $C$. compressus in paired shell fit categories that investigated conspecifics' shells.

\section{Effect of Shell Fit on Shell-Investigation Behavior}

More crabs investigated conspecifics' shells when they were in a worsefitting shell than when they were in a better-fitting shell (Table 2). Shell fit significantly influenced shell investigation in crabs that started with a good shell fit (binomial test of 18:4, $P=0.0022$ ) and in crabs that started with a bad shell fit $(16: 2, P=0.0007)$. Since the starting shell fit did not affect this pattem of behavior, a pooled test of the results is possible and confirms that shell investigation was significantly influenced by shell fit $(34: 6, P<0.0005)$. Similarly, more crabs exchanged shells when they were in a worse-fitting shell than when they were in a better-fitting shell (Table 3). This effect is not significant when crabs that started with a good shell fit (binomial test of $8: 2, P=0.0547$ ) 
Table 2. Number of Crabs Investigating Conspecifics' Shells when Placed in GoOd-FitTING OR BAD-FitTing SHElls ${ }^{a}$

\begin{tabular}{cccccccrr} 
& & \multicolumn{2}{c}{ Bad shell } & & & \multicolumn{2}{c}{ Bad shell } \\
\cline { 3 - 8 } A & & INV & NOT & B & & & INV & NOT \\
\hline $\begin{array}{c}\text { Good } \\
\text { shell }\end{array}$ & INV & 5 & 4 & Good & INV & 3 & 2 \\
& NOT & 18 & 23 & shell & NOT & 16 & 29 \\
\hline
\end{tabular}

${ }^{a} \mathrm{~A}$ : crabs originally in good-fitting shells, later placed in bad-fitting shells; B: crabs originally in bad-fitting shells, later placed in good-fitting shells. INV = crabs that investigated conspecifics' shells; NOT $=$ crabs that did not investigate.

Table 3. Number of Crabs Exchanging Shells when Placed in Good-Fitting or BAD-FITTING SHELLS

\begin{tabular}{ccccccccr} 
& & \multicolumn{2}{c}{ Bad shell } & & & \multicolumn{2}{c}{ Bad shell } \\
\cline { 3 - 7 } A & & EXCH & NOT & B & & & EXCH & NOT \\
\hline Good & EXCH & 2 & 2 & Good & EXCH & 0 & 1 \\
shell & NOT & 8 & 38 & $\begin{array}{c}\text { shell } \\
\text { NOT }\end{array}$ & NOT & 6 & 43
\end{tabular}

\footnotetext{
${ }^{a} \mathrm{~A}$ : crabs originally in good-fitting shells, later placed in bad-fitting shells; $\mathrm{B}$ : crabs originally in bad-fitting shells, later placed in good-fitting shells. EXCH = crabs that exchanged shells; NOT $=$ crabs that did not exchange shells.
}

are examined separately from crabs that started with a bad shell fit $(6: 1, P=$ $0.0625)$. However, the starting shell fit did not affect the pattern of this behavior, and a pooled test of the resuits does reveal a significant effect of shell fit (14:3, $P=0.0064)$.

\section{Comparison of Shell Fits between Sites and Sexes}

The results of the ANCOVAs of shell-fit ratios for juveniles and adults are displayed as adjusted least-squares means (Table 4). For juveniles, no significant effects on shell-fit ratios were found due to sex $\left(F_{1,89}=0.87, P=0.354\right.$, Table 4) or site $\left(F_{1,89}=0.53, P=0.468\right.$, Table 4$)$. Thus, the shell fits of juveniles at Achotines and Naos, males and females, were not significantly different. For adults, significant effects were found due to sex $\left(F_{2.454}=18.42, P<0.001\right.$, Table 4), site $\left(F_{1,454}=89.91, P<0.001\right.$, Table 4), and an interaction between site and $\operatorname{sex}\left(F_{2,454}=3.19, P=0.042\right.$, Table 4). At Achotines, the shell-fit ratios of males and females were not significantly different, but both males and 
Table 4. Adjusted Least-Squares Means of Shell Fit Ratios for Juvenile Males and Females and Adult Males, Females, and Gravid Females at ACHOTINES AND NAOS ${ }^{a}$

\begin{tabular}{lll}
\hline & Achotines & Naos \\
\hline Juveniles & 0.508 & 0.519 \\
Males & & \\
$\quad$ Females & 0.522 & 0.484 \\
Adults & & \\
$\quad$ Males & $0.645 \mathrm{a}$ & $0.599 \mathrm{~b}$ \\
Females & $0.637 \mathrm{a}$ & $0.571 \mathrm{c}$ \\
Gravid fernales & $0.603 \mathrm{~b}$ & $0.569 \mathrm{bc}$ \\
\hline
\end{tabular}

${ }^{a}$ Identical letters after adult means indicate pairs that are not significantly different $(P>0.05)$.

females had significantly higher shell-fit ratios than gravid females. Thus, gravid females were in better-fitting shells than males or females. At Naos, the shellfit ratios of males and females were not significantly different and the shell-fit ratios of gravid females were not significantly different and the shell-fit ratios of gravid females were not significantly different than those of females. However, gravid females did have significantly lower shell-fit ratios than males. The shell-fit ratios of males and females at Achotines were significantly higher than those of males and females at Naos, but the shell-fit ratios of gravid females at Achotines were not significantly different than those of gravid females at Naos.

\section{Response Time to Shell-Investigation Cues at Different Sites}

At Achotines, land hermit crabs were attracted to conspecific hemolymph at a rate of $1.98 \mathrm{crabs} / \mathrm{min}$ (SD 1.11), while at Naos, crabs were attracted at a rate of $0.29 \mathrm{crabs} / \mathrm{min}$ (SD 0.15), a significantly lower rate of attraction ( $t=$ $5.230,22 d f, P<0.001)$.

\section{Distribution of Shell-Investigation Cues}

In test of hemolymph and extracts from stimulus species, rather than whole crushed stimuli, the proportion of crabs investigating conspecifics' shells varied significantly between different stimuli $(G=57.68>15.09,5 d f, P<0.01)$. Seawater, $N$. scabricosta, and $O$. gaudichaudii formed a homogeneous group that did not stimulate shell investigation $\left(G_{H}=2.878<11.07,5 d f, P>0.05\right)$, while $C$. obscurus, $C$. compressus hemolymph, and $C$. compressus crushed in a vial formed a homogeneous group that did stimulate shell investigation $\left(G_{H}\right.$ $=7.758<11.07,5 d f, P>0.05$ ). Shell-investigation cues are therefore present in $C$. obscurus extract, $C$. compressus hemolymph, and crushed $C$. compressus. 


\section{Detection of Shell-Investigation Cues of Other Species}

C. compressus Filled-Shell Bioassay. The proportion of crabs investigating the filled shell varied significantly between odor stimuli $(G=29.44>13.28$, $4 d f, P<0.01$ ). Seawater and $N$. fulgurans formed a homogeneous group that did not stimulate shell investigation $\left(G_{H}=0.008<9.488,4 d f, P>0.05\right)$, while $C$. clypeatus, $C$. antillensis, and $C$. compressus formed a homogeneous group that did stimulate shell investigation $\left(G_{H}=4.57<9.488,4 d f, P\right\rangle$ 0.05 ).

C. obscurus Bioassays. For all stimuli at Achotines and Naos, the number of crabs responding after the addition of seawater did not change significantly from the number of crabs responding before the addition of seawater (Table 5). The number of crabs responding after the addition of stimuli did not change significantly for $O$. gaudichaudii, $C$. compressus, or $C$. clypeatus (Table 5). $C$. obscurus extract significantly increased the number of crabs investigating conspecifics' shells at Achotines and at Naos (Table 5). Shell investigation was also significantly stimulated by $N$. scabricosta, $N$. fulgurans, and C. antillensis (Table 5).

C. antillensis Bioassays. For all stimuli, the number of crabs responding after the addition of seawater did not change significantly from the number of crabs responding before the addition of seawater (Table 6). The number of crabs responding after the addition of stimuli did not change significantly for $C$. compressus or C. clypeatus (Table 6). C. antillensis extract significantly increased the number of crabs investigating conspecifics' shells, as did extracts of $N$. fulgurans, $N$. scabricosta, and C. obscurus (Table 6).

C. clypeatus Bioassays. C. clypeatus investigated conspecifics' shells significantly more often in response to cues from conspecific hemolymph, C. obscurus extract, $C$. antillensis extract, and $C$. compressus hemolymph (Table 7 ). The number of crabs investigating did not significantly change after the addition of $N$. fulgurans extract or $N$. scabricosta extract (Table 7).

\section{Volatile Cue Isolation}

Eluents of $C$. compressus odors collected at $0^{\circ} \mathrm{C}, 100^{\circ} \mathrm{C}$, and $130^{\circ} \mathrm{C}$ stimulated investigation of filled shells, while eluents from collection at $150^{\circ} \mathrm{C}$ and $200^{\circ} \mathrm{C}$ did not (Table 8). Tests of eluents from several species of crabs showed that collections at $130^{\circ} \mathrm{C}$ from $C$. compressus, C. clypeatus, $C$. obscurus, and C. antillensis were all effective in generating investigation of filled shells, while $150^{\circ} \mathrm{C}$ collections from these species and both collections from the control and $O$. gaudichaudii were not stimulating (overall $G=70.71>33.14,11 d f, P<$ 0.005 ; multiple comparison $G=65.17>33.14,11 d f, P<0.005$ ). Tests of $130^{\circ} \mathrm{C} \mathrm{C}$. obscurus eluent, which stimulated shell investigation in $C$. compressus, showed no stimulation of shell investigation in $C$. obscurus (seawater addi- 
Table 5. Proportion of $C$. obscurus that Investigated Conspecifics' Shells in RESPONSE TO VARIOUS STIMULI ${ }^{a}$

\begin{tabular}{|c|c|c|c|}
\hline Stimulus & $\begin{array}{c}\text { Percent } \\
\text { investigating }\end{array}$ & $G$ & $P$ \\
\hline Control & 36 & & \\
\hline Seawater & 30 & 0.80 & $>0.05$ \\
\hline o. gaudichaudii & 36 & 0.83 & $>0.05$ \\
\hline Control & 34 & & \\
\hline Seawater & 36 & 0.09 & $>0.05$ \\
\hline N. scabricosta & 62 & 13.89 & $<0.001$ \\
\hline Control & 40 & & \\
\hline Seawater & 40 & 0.00 & $>0.05$ \\
\hline C. obscurus & 62 & 9.82 & $<0.005$ \\
\hline Control & 34 & & \\
\hline Seawater & 36 & 0.09 & $>0.05$ \\
\hline C. compressus & 40 & 0.34 & $>0.05$ \\
\hline Control & 30 & & \\
\hline Seawater & 28 & 0.12 & $>0.05$ \\
\hline N. fulgurans & 60 & 18.42 & $<0.001$ \\
\hline Control & 30 & & \\
\hline Seawater & 33 & 0.12 & $>0.05$ \\
\hline C. obscurus & 70 & 23.50 & $<0.001$ \\
\hline Control & 43 & & \\
\hline Seawater & 30 & 2.66 & $>0.05$ \\
\hline C. antillensis & 73 & 30.62 & $<0.001$ \\
\hline Control & 34 & & \\
\hline Seawater & 32 & 0.09 & $>0.05$ \\
\hline C. clypeatus & 34 & 0.09 & $>0.05$ \\
\hline
\end{tabular}

"The first four assays shown were conducted at Achotines, the remaining at Naos.

tion: $G=0.00>3.841,1 d f, P>0.05$; ethanol addition: $G=0.056<$ $3.841,1 d f, P>0.05$; eluent addition: $G=0.056<3.841,1 d f, P>0.05$ ).

\section{DISCUSSION}

Land hermit crabs locate dead conspecifics by detecting volatile chemical cues (Small and Thacker, 1994). Land hermit crabs attracted to a shell source by odors may be attracted by feeding cues rather than by shell cues. The visual stimulus of a shell at an odor source might then stimulate shell-investigation 
Table 6. Proportion of $C$. antillensis that Investigated Conspecifics' Shells in Response to Various STIMULI

\begin{tabular}{lccc}
\hline \multicolumn{1}{c}{ Stimulus } & $\begin{array}{c}\text { Percent } \\
\text { investigating }\end{array}$ & $G$ & $P$ \\
\hline Control & 40 & & \\
Seawater & 43 & 0.10 & $>0.05$ \\
$N$. scabricosta & 60 & 4.94 & $<0.05$ \\
Control & 35 & & \\
Seawater & 40 & 0.43 & $>0.05$ \\
N. fulgurans & 58 & 4.97 & $<0.05$ \\
Control & 40 & & \\
Seawater & 40 & 0.00 & $>0.05$ \\
C. obscurus & 58 & 4.97 & $<0.05$ \\
Control & 43 & & \\
Seawater & 33 & 1.68 & $>0.05$ \\
C. antillensis & 60 & 12.69 & $<0.001$ \\
Control & 45 & & \\
Seawater & 38 & 0.92 & $>0.05$ \\
C. compressus & 40 & 0.11 & $>0.05$ \\
Control & 40 & & \\
Seawater & 38 & 0.10 & $>0.05$ \\
C. clypeatus & 38 & 0.00 & $>0.05$ \\
& & & \\
\hline
\end{tabular}

behavior (Hazlett, 1982; Orihuela et al., 1992), with the visual cues acting separately from the olfactory cues that initially attracted a crab to the area. Crabs attracted to dead conspecifics show less feeding and more investigation of conspecifics' shells than crabs attracted to other odor sources. The presence of an empty shell at an odor source visually stimulates shell-investigation behaviors, generating the same levels of investigation of empty shells and shell exchange at all odor sources. Since intact empty shells are rarely encountered on beaches (personal observation; Ball, 1972), it is not surprising that they would generate a high amount of shell-investigation activity when encountered. In the absence of shells, odors from conspecifics and a marine hermit crab stimulated shell investigation in $C$. compressus, while the odor of $B$. sessilis flowers and other foods did not.

Odors that attracted crabs to food sources or shell sources separated responding crabs into two response categories prior to visual stimulation by an empty shell or conspecifics' shells. Crabs attracted to food odors are in betterfitting shells and show less shell-investigation behavior than crabs attracted to 
Table 7. Proportion of C. clypeatus that Investigated Conspecifics' Shells in RESPONSE TO VARIOUS STIMULI

\begin{tabular}{lccc}
\hline \multicolumn{1}{c}{ Stimulus } & $\begin{array}{c}\text { Percent } \\
\text { investigating }\end{array}$ & $G$ & $P$ \\
\hline Control & 28 & 2.91 & $>0.05$ \\
N. scabricosta & 40 & & \\
Control & 30 & 0.33 & $>0.05$ \\
N. fulgurans & 33 & & \\
Control & 28 & 13.33 & $<0.001$ \\
C. obscurus & 55 & & \\
Control & 35 & 10.34 & $<0.005$ \\
C. antillensis & 60 & & \\
Control & 38 & 6.55 & $<0.025$ \\
C. compressus & 58 & & \\
Control & 20 & 20.72 & $<0.001$ \\
C. clypeatus & 53 & & \\
\hline
\end{tabular}

Table 8. Percent of $C$. compressus Investigating Filled Shell in Response to Eluents of $C$. compressus Volatiles Collected at Different Temperatures, C. compressus HeMOlymph CONTROL, AND ETHANOL CONTROL

\begin{tabular}{cccccccc}
\hline $\begin{array}{c}\text { Temperature } \\
\left({ }^{\circ} \mathrm{C}\right)\end{array}$ & $\begin{array}{c}\text { Eluent } \\
(\%)\end{array}$ & $\begin{array}{c}\text { Hemolymph } \\
(\%)\end{array}$ & $G$ & $P$ & $\begin{array}{c}\text { Ethanol } \\
(\%)\end{array}$ & $G$ & $P$ \\
\hline 0 & 87 & 70 & 1.41 & $>0.20$ & 39 & 10.26 & $<0.005$ \\
100 & 64 & 79 & 0.68 & $>0.40$ & 40 & 3.12 & $<0.10$ \\
130 & 76 & 67 & 0.55 & $>0.40$ & 37 & 8.81 & $<0.005$ \\
150 & 5 & 39 & 7.12 & $<0.01$ & 20 & 1.92 & $>0.10$ \\
200 & 43 & 78 & 5.94 & $<0.05$ & 48 & 0.10 & $>0.70$ \\
\hline
\end{tabular}

dead conspecifics. Crabs collected haphazardly display an intermediate level of shell investigation and are in intermediate shell fits. This correlation of shell fit and likelihood of displaying shell-investigation behaviors is causative. Moving crabs from worse-fitting shells to better-fitting shells reduces the amount of shell investigation they display, while moving crabs from better-fitting shells to worsefitting shells increases the amount of shell investigation they display. A similar pattern is found in the marine hermit crab Clibanarius vittatus, for which small changes in shell fit result in large changes in behavior (Rittschof, 1980a; Ritt- 
schof et al., 1992; Katz and Rittschof, 1993). Moving crabs into smaller shells increases the amount of shell investigation observed in $C$. vittatus, while moving crabs into larger shells decreases the amount of shell investigation observed (Katz and Rittschof, 1993). Shell fit, therefore, not only influences the probability of shell-investigation behavior being displayed at a given odor source, but whether or not an individual is attracted to feeding cues or shell cues. Attraction to feeding cues may also be related to the limitations that shell fit places on growth rate. Hermit crabs in poorly fitting shells grow more slowly than crabs in better-fitting shells (Markham, 1968; Fotheringham, 1976). Crabs in poorly fitting shells may therefore eat less and be less attracted to food odors, while crabs in better-fitting shells may seek food more frequently to attain a higher growth rate.

C. compressus gravid females are in better-fitting shells than males and nongravid females at Achotines. The same pattern is found at Naos, but the crabs at Naos are in better-fitting shells overall than the crabs at Achotines, demonstrating that shell fit does vary between land hermit crab populations (Abrams, 1978). The difference in shell fit between gravid and nongravid females suggests that only females in better-fitting shells invest in reproduction. The eggs of land hermit crabs are protected from desiccation by a properly fitting shell (De Wilde, 1973). Poorly fitting shells may limit clutch size (Wilber, 1989) in addition to increasing the risk of desiccation. Bertness (1981) has reported that some marine hermit crabs (Clibanarius albidigitus, C. obscurus, and Pagurus sp.) in relatively smaller shells reproduce more frequently and have larger clutch sizes than those in relatively larger shells. In contrast, Bach et al. (1976) reported that Clibanarius tricolor females in better-fitting shells have a larger clutch size than females in worse-fitting shells. Shell fit may therefore exert different influences on reproduction in different groups of hermit crabs. Since female land hermit crabs in better-fitting shells are more likely to reproduce successfully and male land hermit crabs manipulate a female' shell during courtship (Page and Willason, 1982; Dunham and Gilchrist, 1988), I hypothesize that male land hermit crabs may prefer to mate with females in better-fitting shells. Alternatively, females may not mate unless they are in better-fitting shells.

Differences in shell fit between populations of land hermit crabs at Achotines and Naos are evident in differences in the responses of these populations to shell-investigation cues. The lower levels of shell-investigation activity and better shell fits observed at Naos could be related to a larger supply of large $N$. scabricosta shells, higher predation rates on crabs in poorly fitting shells, or lower juvenile recruitment. These factors would decrease the number of crabs in poorly fitting shells, which would in turn decrease the number of crabs actively searching for shells. Crabs at Naos are less active in general than crabs at Achotines, coming out onto the beach only at dusk and returning to shelter well 
before dawn. In contrast, crabs at Achotines are active on the beach from one to two hours before dusk, all through the night, returning to shelter by $1100 \mathrm{hr}$, at which time the beach is no longer shaded and begins to heat up rapidly. Peak activity at both sites occurs on falling tides near dawn and disk, after new and full moons.

C. compressus responds to shell-investigation cues in the hemolymph of conspecifics and in extracts of a local marine hermit crab, $C$. obscurus, but not from a snail whose shell these two hermit crabs use, $N$. scabricosta, nor from a brachyuran crab found on the same beach, $O$. gaudichaudii. When tested with similar species from the Caribbean coast of Panama, $C$. compressus responds to shell-investigation cues from a congener, $C$. clypeatus; a marine hermit crab, $C$. antillensis; but not from a snail whose shell is inhabited by these two species, $N$. fulgurans. Likewise, $C$. clypeatus responds to shell-investigation cues from both species of land hermit crabs and marine hermit crabs, but not from either of the snail species. The marine hermit crabs from the Pacific and Caribbean coasts of Panama, both diogenids, respond to shell-investigation cues from both marine hermit crab species and both snail species, but not from the land hermit crabs or the brachyuran crab.

Since land hermit crabs can detect volatile shell-investigation cues from marine hermit crabs, these volatile compounds were most likely present in the ancestral hermit crabs that first moved onto land. A detection system for these cues probably evolved during the transition to a terrestrial environment. The nonvolatile peptide cues from gastropod tissue used to locate shell sources from a distance in water (Kratt and Rittschof, 1991) can not be used in this manner on land. However, land hermit crabs have retained a detection system for peptide cues from gastropod tissue, since newly metamorphosed juveniles can find their first shell underwater by detecting these cues (Gilchrist, 1991). The shell-investigation cues released from the hemolymph of marine hermit crabs are small ( $<500 \mathrm{Da})$, water-soluble, and could be volatile (Rittschof, personal communication; Rittschof et al., 1992).

Land hermit crabs do not respond to shell-investigation cues from snails, possibly because there are no volatiles found uniquely in snails and not in other carrion sources, preventing the differentiation of carrion likely to have shells and carrion not likely to have shells. Predators of snails on land (e.g., birds, Gecarcinus) are also less likely to leave an intact shell than are predatory marine gastropods (McLean, 1974). The cost of a detection system may not be balanced by the frequency of encountering an intact shell at the source of the cue. Dead or dying marine hermit crabs could frequently be left in the intertidal zone with their shells as the tide recedes, making it profitable for land hermit crabs to be able to detect them.

Although land hermit crabs are derived from marine hermit crabs (McLaughlin, 1983), diogenid marine hermit crabs do not respond to shell- 
investigation cues from land hermit crabs, suggesting that the particular cues found in the hemolymph of marine hermit crabs are not present in the hemolymph of land hermit crabs. Land hermit crabs may have lost these cues, indicating that marine hermit crabs may maintain shell-investigation cues in their hemolymph at some cost. This idea of a cost associated with maintaining cues in hemolymph would not be supported if these cues serve another, primary function in the crab.

In addition, two separate cue detection systems may exist. First, marine hermit crabs may detect a nonvolatile peptide-based cue released from gastropod tissues that land adult hermit crabs can not detect because it can not be transmitted in air. Second, marine and land hermit crabs may detect another, unidentified type of cue from hermit crab hemolymph that is sufficiently water soluble and volatile to be transmitted in both water and air.

The shell-investigation cues of land hermit crabs may have diverged from those of marine hermit crabs such that the diogenid marine hermit crabs tested in these experiments can not detect land hermit crab cues. Rittschof et al. (1992) have shown that $C$. vittatus, a diogenid marine hermit crab, does not respond to shell-investigation cues from Pagurus longicarpus and Pagurus pollicaris, two pagurid marine hermit crabs, while $P$. longicarpus and $P$. pollicaris do respond to cues from $C$. vittatus. This evidence suggests that the evolution of hermit crab shell-investigation cues can be studied by determining if cue detection abilities are correlated with hermit crab phylogeny. Identification of the cues of several species of hermit crabs could reveal how shell-investigation cues have changed and which groups of hermit crabs share similar cues.

Isolation of volatile shell-investigation cues is possible by collecting volatile compounds onto Tenax at different temperatures. Biologically active compounds are present in $130^{\circ} \mathrm{C}$ collections from land hermit crabs and marine hermit crabs, but not in $150^{\circ} \mathrm{C}$ collections, suggesting that the cues from the four species that stimulated $C$. compressus shell-investigation behavior are similar. The $130^{\circ} \mathrm{C}$ collection of $C$. obscurus volatiles do not stimulate shell investigation in $C$. obscurus, indicating that the stimulant molecules of land hermit crabs are different from those of marine hermit crabs. No volatiles collected from controls or $O$. gaudichaudii stimulate shell investigation. The next step in this procedure will be to analyze each collection of volatiles using gas chromatography. Compounds present in the control, $O$. gaudichaudii, or $150^{\circ} \mathrm{C}$ collections can be ruled out as potential shell cues, leaving compounds present in $130^{\circ} \mathrm{C}$ collections from marine hermit crabs and land hermit crabs as candidate cues. These candidate cues can then be identified by mass spectroscopy.

Acknowledgments-Research at the Achotines Laboratory was made possible by the InterAmerican Tropical Tuna Commission. A Smithsonian Tropical Research Institute Short-Term Fellowship provided support at the Naos Marine Laboratory and the Galeta Marine Laboratory. Additional support was provided by a University of Michigan Regents Fellowship, a University of 
Michigan Rackham Dissertation Grant, a Grant-in-Aid of Research from Sigma Xi, and the LernerGray Fund for Marine Research of the American Museum of Natural History. Many thanks to: B. Hazlett, D. Rittschof, and M. Small for comments on the experiments and manuscript; V. Scholey, J. Stadler, and the staff of the Achotines Laboratory for valuable assistance at Achotines; J. Christy, U. Schober, and the staff of STRI for ideas, suggestions, and logistical support at Naos and Galeta; and $R$. Raguso for his volatile collection expertise.

\section{REFERENCES}

ABrams, P. 1978. Shell selection and utilization in a terrestrial hermit crab, Coenobita compressus (H. Milne Edwards). Oecologia 34:239-253.

BaCH, C., HaZleTt, B., and RITTSChOF, D. 1976. Effects of interspecific competition on fitness of the hermit crab Clibanarius tricolor. Ecology 57(3):579-586.

BALL, E.E. 1972. Observations on the biology of the hermit crab, Coenobita compressus H. Milne Edwards (Decapoda; Anomura) on the west coast of the Americas. Rev. Biol. Trop. 20(2):265273.

BERTNESS, M.D. 1981. Pattern and plasticity in tropical hermit crab growth and reproduction. Am. Nat. 117(5):754-773.

Childress, J.R. 1972. Behavioral ecology and fitness theory in a tropical hermit crab. Ecology 53:960-964.

Ciccioli, P., Bertoni, G., Brancaleoni, E., Fratarcangeli, R., and Bruner, F. 1976. Evaluation of organic pollutants in the open air and atmospheres in industrial sites using graphitized carbon black traps and gas chromatographic-mass spectrometric analysis with specific detectors, J. Chromatogr. 126:757-770.

Conover, W.J. 1980. Practical Nonparametric Statistics, 2nd ed. John Wiley, \& Sons, New York.

DE WILDE, P.A.W.J. 1973. On the ecology of Coenobita clypeatus in Curaçao with reference to reproduction, water economy and osmoregulation in terrestrial hermit crabs. Stud. Fauna $\mathrm{Cu}$ raçao 44:1-138.

DunhaM, D.W., and GilChrist, S.L. 1988. Behavior, pp. 97-138 in W.W. Burggren and B.R. McMahon (eds.). Biology of the Land Crabs. Cambridge University Press, Cambridge.

Fotheringham, N. 1976. Effects of shell stress on the growth of hermit crabs. J. Exp. Mar. Biol. Ecol. 23:655-671.

GILCHRIST, S.L. 1991. Behavior of crustacea: ecological and social perspectives. Mem. Queens. Mus. 31:263-275.

HazLeTt, B.A. 1981. The behavioral ecology of hermit crabs. Annu. Rev. Ecol. Syst. 12:1-22.

HAZLETT, B.A. 1982. Chemical induction of visual orientation in the hermit crab Clibanarius vittatus. Anim. Behav. 30(4):1259-1260.

HAZLETT, B.A 1989. Mating success of male hermit crabs in shell generalist and shell specialist species. Behav. Ecol. Sociobiol. 25:119-128.

HAZLETT, B.A., and BARON, L.C. 1989. Influence of shells on mating behavior in the hermit crab Calcinus tibicen. Behav. Ecol. Sociobiol. 24:369-376.

KATZ, J., and Rutrschof, D. 1993. Alarm/Investigation responses of hermit crabs as related to shell fit and crab size. Mar. Behav. Physiol. 22:171-182.

KelloGg, C.W. 1976. Gastropod shells: A potentially limiting resource for hermit crabs. J. Exp. Mar. Biol. Ecol. 22:101-111.

KRATT, C.M., and RitTsChOF, D. 1991. Peptide attraction of hermit crabs Clibanarius vittatus Bosc: Roles of enzymes and substrates. J. Chem. Ecol. 17(12):2347-2365.

KURTA, A. 1982. Social facilitation of foraging behavior by the hermit crab Coenobita compressus in Costa Rica. Biotropica 14:132-136. 
MARKHAM, J.C. 1968. Notes on growth-patterns and shell-utilization of the hermit crab Pagurus bernhardus (L.). Ophelia 5:189-205.

Mclaughlin, P.A. 1983. Hermit crabs-are they really polyphyletic? J. Crust. Biol. 3(4):608621.

MCLEAN, R.B. 1974. Direct shell acquisition by hermit crabs from gastropods. Experientia 30(2):206-208.

Neter, J., Wasserman, W., and KutNer, M.H. 1990. Applied Linear Statistical Models, 3rd ed. Richard Irwin, Boston.

Orinuela, B., Diaz, H., Forward, R.B., JR., and Rutrschof, D. 1992. Orientation of the hermit crab Clibanarius vittatus (Bosc) to visual cues: Effects of mollusc chemical cues. J. Exp. Mar. Biol. Ecol. 164:193-208.

PAGE, H.M., and WILlason, S.W. 1982. Distribution patterns of terrestrial hermit crabs at Enewetak Atoll, Marshall Islands. Pac. Sci. 36(1):107-117.

PATt, J.M., RhoAdes, D.F., and CoRkILL, J.A. 1988. Analysis of the floral fragrance of Platanthera stricta. Phytochemistry 27(1):91-95.

Provenzano, A.J., Jr. 1960. Notes on Bermuda hermit crabs (Crustacea: Anomura). Bull. Mar. Sci. 10:117-124.

RutTSCHOF, D. 1980a. Chemical attraction of hermit crabs and other attendants to simulated gastropod predation sites. J. Chem. Ecol. 6(1):103-118.

RITTSCHOF, D. 1980b. Enzymatic production of small molecules attracting hermit crabs to simulated gastropod predation sites. J. Chem. Ecol. 6(3):665-675.

RITTSCHOF, D., and SUTHERLAND, J.P. 1986. Field studies on chemically mediated behavior in land hermit crabs: Volatile and nonvolatile odors. J. Chem. Ecol. 12(6):1273-1284.

RitTschof, D., KratT, C.M., and Clare, A.S. 1990. Gastropod predation sites: The role of predator and prey in chemical attraction of the hermit crab Clibanarius vittatus. J. Mar. Biol. Assoc. U.K 70:583-596.

Rittschof, D., Tsai, D.W., Massey, P.G., Blanco, L., Keuber, G.L., JR., and HaAs, R.J., Jr. 1992. Chemical Mediation of behavior in hermit crabs: Alarm and aggregation cues. J. Chem. Ecol. 18(7):959-984.

Small, M.P., and Thacker, R.W. 1994. Land hermit crabs use odors of dead conspecifics to locate shell sources. J. Exp. Mar. Biol. Ecol.

SOKal, R.R., and RoHLF, F.J. 1981. Biometry. W.H. Freeman, San Francisco.

SPIGHT, T.N. 1977. Availability and use of shells by intertidal hermit crabs. Biol. Bull. 152:120133.

VANCE, R.R. 1972. Competition and mechanism of coexistence in three sympatric species of intertidal hermit crabs. Ecology 53:1062-1074.

WILBUR, T.P., JR. 1989. Associations between gastropod shell characteristics and egg production in the hermit crab Pagurus longicarpus. Oecologia 81:6-15. 